\title{
A FUNÇÃo SOCIAL DA TERRA E AS AÇÕES POSSESSÓRIAS
}

Adegmar José Ferreira* Maria Cristina Vidotte Blanco Tarrega**

Rangel Donizete Franco ${ }^{* * *}$

\section{Resumo}

Discute-se neste artigo a relação entre a função social da terra e as ações possessórias desde uma perspectiva da hermenêutica jurídica no campo do direito agrário. Argumenta-se a favor da possibilidade interpretativa de se discutir a função social da terra nas ações possessórias (interdito, manutenção e reintegração de posse) como requisito de tutela da posse, na liminar ou na sentença. Para exemplificar como se deve tratar a questão nas ações possessórias se trabalha com a importância da posse para a efetivação da função social da terra, com o significado jurídico desse princípio no direito agrário, com o critério socioambiental desse princípio e com a constatação probatória da realização do citado princípio.

Palavras-Chave: Direito Agrário. Conflitos Possessórios. Hermenêutica Jurídica.

\section{INTRODUÇÃO}

O tema do presente artigo é a relação entre a função social da terra e as ações possessórias.

A questão escolhida justifica-se pelo uso recorrente das ações possessórias em conflitos agrários, ou melhor, pelo aprisionamento desses conflitos na dogmática do procedimento especial individualista das ações possessórias.

Outro fator motivador da escolha desse tema é o crescente estoque de terras improdutivas no Brasil (estimado em 134 milhões de hectares), a exigir a apuração e a efetiva aplicação de mecanismos jurídicos para tentar

\footnotetext{
* Doutor em Educação pela PUC-GO. Mestre em Direito Agrário pela UFG. Professor na Graduação e no Mestrado em Direito Agrário da UFG. Juiz de Direito (TJGO). adegmarjferreira@uol.com.br

${ }^{* *}$ Doutora em Direito pela PUC-SP, com estágio pós-doutoral em Coimbra-Portugal. Professora Titular de Direito Empresarial e Agrário da UFG. Sub-Coordenadora do Programa de Mestrado em Direito Agrário da UFG. mcvidotte@uol.com.br

${ }^{* * *}$ Mestre em Direito Agrário pela UFG. Professor na FASAM e Analista Judiciário na Justiça Estadual de Goiás. Foi bolsista CAPES (2010-2012). eufrancoj@yahoo.com.br
} 
desconstruir esse cenário de intensificação da concentração da terra no Brasil. ${ }^{1}$

A base empírica de reflexão parte dos dados levantados em pesquisa cujo relatório final se encontra publicado, notadamente aqueles dados pertinentes às ações possessórias no Estado de Goiás, a partir do método de estudo de casos em autos de processos relativos a ações possessórias. ${ }^{2}$

A base teórica do trabalho é a perspectiva hermenêutica, a partir da qual se compreende, também a partir do dado fático e do dado normativo, ou melhor, se descortina a possibilidade interpretativa de se discutir a função social da terra nas ações possessórias.

O objetivo principal é discutir o tipo de relação possível entre a função social da terra e as ações possessórias.

\section{As Ações Possessórias: Notas Sobre Seu Campo Denotativo e Suas Caracteristicas}

De se notar que, neste artigo, não se incluem no campo denotativo da expressão "ações possessórias", a ação de usucapião, a de nunciação de obra nova, os embargos de terceiro, a ação de dano infecto, que, ademais envolverem discussão sobre posse, não são de utilização corrente nos conflitos coletivos pela posse e propriedade da terra no Brasil.

Também não é o caso da ação de imissão de posse, a qual, embora não mais regulada no Código de Processo Civil, recebe normatização no DecretoLei n. ${ }^{\circ} 70 / 66$, pertinente à execução extrajudicial de imóveis vinculados ao sistema nacional de habitação, sendo aplicada nesse campo, e na Lei n. ${ }^{\circ}$ $8.245 / 1991$, em relação a imóveis locados.

Assim, são objeto de consideração neste artigo apenas as ações de interdito proibitório, de manutenção de posse e de reintegração de posse, normatizadas juridicamente nos artigos 926 a 933 do Código de Processo Civil. 
No tocante ao interdito proibitório, de destacar seus elementos, que, segundo Nascimento (1986, p. 118), são:

\begin{abstract}
“[...] a) - ameaça injusta; b) - justo receio; c) - iminência da agressão; d) - veto com preceito e cominação. Neste último elemento, insere-se o preceito judicial de um veto - uma proibição de fazer ou um mandamento de não fazer ao requerido do interdito - e de uma cominação, uma pena pecuniária que, descumprido o preceito, o requerido transgressor deve pagar ao requerente ameaçado [...]".
\end{abstract}

Note-se que a concepção teórica dos elementos da ação de interdito proibitório acolhe uma perspectiva preventiva de tutela jurisdicional da posse. O uso da ação, tal como positivado no texto normativo, está disponível para os casos de "ameaça injusta", "justo receio" e "iminência da agressão" à posse.

Ainda que os termos referidos sejam vagos e ambíguos, o critério para a caracterização deles não deve ficar ao discricionário alvedrio de cada sujeito interpretante, mas devem pressupor, no campo fático, a prática de atos concretos que importem na ameaça de turbação ou esbulho à posse.

Quanto à manutenção de posse, seu objeto remete à turbação, que, segundo Nascimento (1986, p. 122), prejudica “[...] o exercício pacífico da posse, sobrepondo ao senhorio de fato outro senhorio que lhe é prejudicial [...]", além de ser “... mais que o esbulho - porque nesse o exercício da posse está impossibilitado [...]".

A definição jurídica do termo "turbação" remete a todo ato que embaraça o livre exercício da posse, pouco importando se exista ou não um dano, tenha ou não o turbador melhor direito sobre a coisa (GOMES, 1998, p. 90). A construção teórica da turbação é ampla o bastante para permitir interpretações extensivas do que, no plano fático, qualifica-se ou não como turbativo.

Assim, no campo das ações possessórias, a depender da formação subjetiva do juiz, da sua ideologia, da influência das mídias, dos seus 
valores, das suas perspectivas teóricas (ou ausência delas) - enfim, dos diversos condicionantes de uma decisão judicial, tão bem apreendidos por Rosa (2006) no contexto das decisões penais, os quais, entende-se neste artigo, podem ser colocados também para as decisões agrárias -, a instalação, por sem-terras, de um acampamento às margens das cercas divisórias de um imóvel rural, por exemplo, poderá ser lido ou não como ato turbativo.

Quanto à reintegração de posse, de destacar que tem por objeto afastar o esbulho, o qual "[...] desfaz o corpus, descaracterizando o elemento material [...]" (NASCIMENTO, p. 123) da posse, restando esta apenas com o animus. Não se pode esquecer que "reintegrar" “[...] é reintegrar quem já estava nessa situação, anteriormente [...]". Assim, não merece reintegração que não se integrava na posse anteriormente.

Um dos pontos mais polêmicos, nas ações de manutenção e reintegração de posse, é sobre a caracterização delas ou com "força nova espoliativa" (posse nova) ou "força velha espoliativa" (posse velha), o que justifica a caracterização das mesmas como sendo de natureza dúplice.

Enquanto a posse nova é de menos de ano e dia, a velha é de ano e dia em diante. Essa distinção é fundamental para se definir o rito (especial ou ordinário) a ser imprimido na condução dos processos instaurados a partir do ajuizamento das ações possessórias. É que, em sendo nova a posse, possivel o pedido e deferimento de medida liminar de proteção possessória. Entretando, em sendo velha ou não tendo sido pedida proteção liminar na de força nova, não se admite tal providência (SILVA, 1993, p. 227).

Essas explicitações conceituais básicas são imprescindíveis ao presente artigo, haja vista que permite diferenciar, e, portanto, evitar confusões terminológicas comumente notáveis. Um exemplo é ter por esbulhado um imóvel rural, em caso de ocupação coletiva de terra que não alcança sequer 5\% da área total do mesmo. Os efeitos de uma liminar, deferida com base no juizo de ocorrência de esbulho, sem haver de fato, podem ser mortíferos, ou, ao menos, lesivos a direitos fundamentais dos 
ocupantes, principalmente se utilizado, de forma excessiva e abusiva, a força pública, no cumprimento de decisões provisórias.

\section{O Problema do Velamento da Questão da Função Social da Terra nas Ações Possessórias}

Delimitado o universo de alcance das ditas "ações possessórias", passa-se a referir-se às questões mais polêmicas nesse campo.

Nessas ações, várias questões polêmicas podem ser postas, pertinente à qualificação dos réus, da citação pessoal, da concessão da liminar, da audiência de justificação prévia, da leitura pelos atores jurídicos em cena nessas ações, notadamente o juiz, e, sobretudo, do cumprimento da função social da posse e da propriedade.

Nesse artigo, interessa expressamente saber se é juridicamente legítimo a exigência de cumprimento da função social da terra nas ações possessórias.

Essa preocupação surgiu a partir dos dados levantados na pesquisa científica. Constatou-se que, no caso do Estado de Goiás, a partir dos 13 autos de processo de ações possessórias analisados, que "[...] o discurso decisório goiano, pelo que se extrai dos casos analisados, é silente sobre a função social da propriedade [...]" (TARREGA et al, p. 56), adjudicando às ocupações coletivas de terras por movimentos sociais respectivos o sentido de violação da regra do respeito à posse de outrem, senão da própria propriedade.

Essa constatação reforça a hipótese de que a falta da consideração da função social da terra nas ações possessórias contribui para a ineficácia desse princípio e contribui para o acirramento dos conflitos agrários, já intensos no Brasil principalmente pelo fato de que "a distribuição da propriedade, especialmente a terra áravel, é escandalosa. No Brasil, por 
exemplo, em 1997, 1\% dos proprietários controla $43 \%$ das terras aráveis, enquanto 153 milhões de hectares são mantidos incultos. Enquanto isso, 5 milhões de camponeses espoliados vagam com suas famílias famélicas pelas estradas desse imenso país" (ZIEGLER, 2003, p. 37-38).

\subsection{A Importância da Posse Para a Função Social da Terra}

Tradicionalmente, se fala numa divisão entre juízo possessório e petitório nessas ações possessórias, de modo a afastar delas discussões outras que não as possessórias Nessa situação, nem mesmo a questão da propriedade poderia ser levantada e debatida nas ações possessórias, a não ser excepcionalmente, nos termos da súmula 487 do STF, do art. 1210, §2 do CC/O2 e do art. 923, do Código de Processo Civil em vigor.

Ocorre que essa compreensão não mais se sustenta desde a perspectiva da teoria da hermenêutica jurídica. Primeiro porque, não raro, ainda na inicial possessória, se invoca o direito de propriedade e a função social da mesma para postular proteção possessória. Segundo porque a riqueza das dimensões da posse permite compreendê-la inclusive como integrante do domínio (ARONNE, 2003, p. 238), adquirindo, assim, a significação de "posse-conteúdo", a qual viabiliza a funcionalização da terra sobre a qual se exercita ou não o direito de propriedade.

O primeiro argumento é aceito até mesmo pela compreensão tradicional sobre a matéria, como destaca Silva (1993, p. 217), quando aponta as situações em que a alegação de dominio torna-se relevante nos juízos possessórios, cuja consequência imediata "haveria de ser o reconhecimento da posse em favor daquele a quem o dominio evidentemente pertencesse" (SILVA, 1993, p. 218).

Ademais, é a partir da fundamentação fático-jurídica - a qual delimita um dos elementos da demanda civil (a causa de pedir) - que se estabelecerá 
o objeto probatório e decisório no processo possessório a se instaurar como as ações respectivas.

Nesse quadro e considerando o ordenamento jurídico numa perspectiva sistemática, cabivel a exigência ao postulante da proteção possessória em conflitos agrários da prova tanto do exercício efetivo da posse quanto do cumprimento da função social, como requisito para deferimento da liminar ou para julgamento de procedência da possessória. Essa a linha compreensiva em que se estrutura a argumentação neste artigo.

$\mathrm{Na}$ jurisprudência, pouquíssimos são os casos em que se admite a visualização das possibilidades de adjudicação de sentidos constitucionais na apreciação judicial de conflitos agrários ${ }^{3}$. Dois exemplos interessam aqui, porque vão de encontro ao tradicional velamento da discussão da questão da função social da terra nas ações possessórias.

O primeiro precedente tem ementa vazada nos seguintes temos:

Decisão atacada: Liminar que concedeu a reintegração de posse da empresa arrendatária em detrimento dos "sem terra". Liminar deferida em primeiro grau suspensa através de despacho proferido nos autos do agravo, pelo desembargador de plantão. Competência da Justiça Estadual. Recurso conhecido, mesmo que descumprindo o disposto no artigo $526 \mathrm{CPC}$, face dissídio jurisprudencial a respeito e porque a demanda versa sobre direitos fundamentais. Garantia a bens fundamentais como mínimo social. Prevalência dos direitos fundamentais das 600 famílias acampadas em detrimento do direito puramente patrimonial de uma empresa. Propriedade: garantia de agasalho, casa e refúgio do cidadão. Inobstante ser produtiva a área, não cumpre ela sua função social, circunstância esta demonstrada pelos débitos fiscais que a empresa proprietária tem perante a União. Imóvel penhorado ao INSS. Considerações sobre os conflitos sociais e o Judiciário. Doutrina local e estrangeira. Conhecido, por maioria; rejeitada a preliminar de incompetência, à unanimidade; proveram o agravo, por maioria. (BRASIL. TRIBUNAL DE JUSTIÇA DO RIO GRANDE DO SUL. AGRAVO DE INSTRUMENTO N. 598.360.402 - SÃO LUIZ GONZAGA - Relatora Desembargadora Elba Aparecida Nicolli Bastos, j. 06.1021998. Disponivel:<http://www.pge.sp.gov.br/centrodeestudos/ 
bibliotecavirtual/dh/volume\%20ii/agravo598360402.htm .> Acesso em: 09 jan. 2011).

A riqueza desse julgado é evidente. Várias questões são colocadas, entre elas a definição do órgão jurisdicional competente para processa e julgar ações possessórias, colisão de direitos, cumprimento da função social e papel do Poder Judiciário para resolver conflitos sociais.

Antes de ter sido proferido o Acórdão, no caso (na ação possessória, tinha sido deferida liminar para reintegração na posse de imóvel rural), cuja ementa foi referida acima, a questão tinha sido apreciada no plantão do dia 17 de setembro de 1998, pelo desembargador Rui Portanova. Na ocasião, o mesmo agregou efeito suspensivo, liminarmente, ao agravo interposto pelo Movimento dos Trabalhadores Sem Terra, para “[...] suspender a execução do despejo até decisão final deste recurso [...]", sob o fundamento de que “[...] a decisão agravada não levou em conta a função social. O despacho agravado não disse palavra a respeito [...]”.

O segundo precedente tem a seguinte ementa:

POSSESSÓRIA. ÁREA RURAL. MST. FUNÇÃO SOCIAL DA PROPRIEDADE. INVESTIGAÇÃO. POSSIBILIDADE. FUNÇÃO SOCIAL DA PROPRIEDADE COMO DIREITO FUNDAMENTAL. CONSTRUÇÃO DE NOVA EXEGESE DA NORMA MATERIAL E PROCEDIMENTAL. INVESTIGAÇÃO DA PRODUTIVIDADE E APROVEITAMENTO DA ÁREA EM AÇÃO POSSESSÓRIA. NECESSIDADE. ART. 5, XXII E XXIII, CF. LEI N ${ }^{\circ}$ 8.629/93. NEGARAM PROVIMENTO. VOTO VENCIDO. (Agravo de Instrumento $\mathrm{N}^{\circ}$ 70003434388, Décima Nona Câmara Cível, Tribunal de Justiça do RS, Relator: Carlos Rafael dos Santos Júnior, Julgado em 06/11/2001).

No voto vencido, do vogal Luiz Augusto Coelho Braga, foi alinhado o seguinte argumento jurídico no sentido de afastar "por completo qualquer discussão a respeito da função social da propriedade na área invadida e pertencente aos agravantes [...], face à ausência do devido processo legal: que seria em sede de ação de desapropriação [...]". E continua, “[...] para a reintegração na posse basta aos autores da ação provar a sua posse, o esbulho praticado pelos réus, a data do esbulho, bem como a perda da posse”. 
Para ele, então, desde uma leitura literal do art. 927 do Código de Processo Civil, a via adequada para se debater a função social da terra não seria as ações possessórias, mas as de desapropriação, em atenção ao devido processo legal.

O argumento não se sustenta juridicamente porque também a propositura das ações possessórias ensejam a instrução do devido processo legal, tal como se dá na propositura de ação de desapropriação, em que se pode discutir, a partir da produção probatória, as eventuais alegações fáticas que forem lançadas quanto à funcionalidade social da terra objeto do litígio.

Vê-se que nessas questões pode haver duas percepções interpretativas: aquela criminalizante, que enxerga na ocupação ou na sua tentativa, um crime, um fato passivel de punição (geralmente esbulho possessório), na linha da "colonização do problema agrário pelo controle penal", como anota Andrade (2003, p. 125) ou como ilícito civil, e a outra, concretizante, que a vê como exercício de direito de cidadania, para implantação da reforma agrária e efetivação e direitos fundamentais e humanos (moradia, trabalho, alimentação etc).

Alfonsin (1998, p. 282) bem apanha essas possibilidades de percepção, ao asseverar que “[...] parece urgente [...] que as lides possessórias se exorcizem de um certo maniqueísmo e enfrentem a possibilidade de, em vez de apuração de ilicitos contra posses, terem de decidirem sobre conflitos entre direitos [...]".

Nessa perspectiva, é possivel averiguar se nas decisões liminares ou nas sentenças, qual opção o judiciário, em cada processo de ação possessória, se pela leitura criminalizante, ou no mínimo, da ilicitude civil, ou conflito de direitos fundamentais da partes envolvidas. Saber o porquê, mesmo em sendo possivel exigir do proprietário a prova do cumprimento da função social da posse e da propriedade nessas ações, não o fez. ${ }^{4}$

A questão da liminar depende, por exemplo, da investigação sobre a posse e, nesse ponto, torna-se útil valer-se das classificações correntes da 
mesma no direito. Vários são os critérios usados para tanto: o temporal (posse nova e posse velha), a justeza (posse justa e posse injusta), o tipo de contato com coisa (posse direta e posse indireta), a natureza (posse civil e posse agrária), presença da boa-fé (posse de boa-fé e posse de má-fé).

No tocante à qualidade da posse, no precedente acima referido, o revisor Mário José Gomes Pereira trabalhou com a ideia da necessidade de se "[...] introduzir, no conceito de posse justa, tratando-se de imóvel rural, um componente de uso, [...] relativo a observância da função social da propriedade [...]", viabilizando assim a funcionalização do exercício possessório. Segundo o revisor, então, seria justa a posse que atendesse a função social da terra, ou seja, cuja a utilização não violasse os arts. $5^{\circ}$, XXIII e 186 da Constituição Federal de 1988.

Outra questão é sobre a significação da função social da terra para o Poder Judiciário. Nos precedentes citados, a semia da expressão está definida. Ocorre que, nos processos analisados referentes ao Estado de Goiás, a questão nem chegou a ser colocada. Assim, necessário saber como opera a lógica da função social da propriedade no direito agrário e no direito civil, como referem Franco e Leite Filho (2011, p. 210):

O Direito Agrário, diferentemente do Direito Civil, tem uma lógica coerente sobre a função social da propriedade, pois garante o direito de propriedade, estabelece condições para que a mesma seja exercida (função social), e, em caso de descumprimento da função social, a propriedade rural deve ser desapropriada e destinada à reforma agrária. Ou seja, por mais que seja propalada a mudança do conteúdo do direito à propriedade civil, a partir da constitucionalização/publicização deste, com surgimento do novo Código Civil (2002), em nada muda o conceito de propriedade, como muitos querem, porque efetivamente não há qualquer sanção àquele que não cumprir a função social. Aqui reside uma diferença substancial entre o Direito Agrário e o Direito Civil, que é o fato do Poder Público poder desapropriar a propriedade e destiná-la a outra pessoa para que dê destinação ao imóvel e cumpra sua função social e os objetivos da Constituição. Por outro lado, isso não ocorre com o Direito Civil. 
Nessa perspectiva, a função social da terra é exigivel nas ações possessórias envolvendo ocupações coletivas por movimentos sociais de luta pela terra, remetendo a questão para exame no campo do direito agrário e não apenas no direito civil, destacando-se que o direito agrário está estruturado em princípios fundamentais, a exemplo da função social da terra (SOUZA FILHO, 2003) e da proteção à posse agrária.

Neste artigo, se opta pelo signo linguístico trabalhado por Marés (2003), de função social da terra, em detrimento daquela corrente na lei, na doutrina e na jurisprudência, de função social da propriedade. É que, com Marés (2003, p. 116), "na realidade quem cumpre uma função social não é a propriedade, que é um conceito, uma abstração, mas a terra, mesmo quando não alterada antropicamente, e a ação humana ao intervir na terra, independentemente do título de propriedade que o Direito ou o Estado lhe outorgue".

Assim, o uso linguístico que eventualmente se faça nesse artigo do termo "função social da propriedade" é apenas a tradução de submissão à tradição linguística materializada no direito.

A concretização ${ }^{5}$ dessa função social ocorre, contudo, pelo exercício da posse agrária, aqui entendida como aquela que traduz

[...] o exercício direto, contínuo, racional e pacífico, pelo possuidor, de atividade agrária desempenhada sobre um imóvel rural, apto ao desfrute econômico, gerando a seu favor um direito de natureza real especial, de variadas consequências jurídicas e visando ao atendimento de suas necessidades sócio-econômicas bem como as da sociedade [...] (LIMA, 1990, p.103).

Tradicionalmente, Savigny (1870) e Ihering (2002) - representantes respectivamente da Escola Histórica e da Jurisprudência dos Interesses (CAMARGO, 2003, p. 75 e 92) - são referências na reflexão sobre o fenômeno possessório, notadamente sobre a natureza jurídica do instituto, no cenário alemão do século XIX. A questão é sobre se a posse traduz um exercício de fato ou se é um direito. 
Atribui-se ao primeiro a autoria da chamada Teoria Subjetiva da Posse, para cuja caracterização se exige tanto o corpus quanto o animus, em que a aquele traduz o "apoderamento da coisa", a "retenção do bem" (ARONNE, 2003, p. 222) e o segundo remete à "vontade de possuir a res" (ARONNE, 2003, p. 222). Ihering (2002), idealizador da Teoria Objetiva da Posse, concebe esta como um direito, cuja caracterização independe do animus. Basta o corpus.

A retomada sintética dessas teorias se justifica na medida em que podem ou não estar presentes, como fundamento para a compreensão da posse, nas decisões judiciais relativas às ações possessórias ou mesmo fundamentar ou não a distinção das noções de posse civil e de posse agrária, muito embora foram pensadas em contexto espaço-temporal (século XIX, na Europa) que em nada se assemelha ao brasileiro do início do século XXI. Além disso, foram criadas num ambiente de discussão na teoria da interpretação jurídica no século XIX, o que justifica a discussão do tema desde a matriz teórica hermenêutica.

Enquanto na posse civil se admite a ficção da posse indireta, caracterizada pela inexistência do corpus (como exemplifica o proprietário que arrenda o imóvel rural de que é titular), a posse agrária não concebe essa forma ficcional de posse, conhecida como indireta. Admite apenas aquela posse direta, angariada no corpus enquanto apreensão física do bem, no caso, a terra (MARQUES, 2005; LIMA, 1990). Isso porque é a partir dela, em sua materialidade, que é possivel o desenvolvimento das atividades agrárias.

Ademais, à posse civil, ao menos no campo legislativo infraconstitucional, não se agrega a perspectiva funcionalista, de serventia dela a valores existenciais, como a realização de direitos fundamentais (ao trabalho, à moradia, à alimentação etc.), e não meramente patrimoniais. Porém, a posse agrária reveste-se de funcionalidades notórias, valendo destacar aqui os objetivos constitucionalmente fixados, a exemplo da efetivação dos direitos fundamentais, inclusive aqueles de cunho transindividuais, como o é a proteção ao meio ambiente. 
Nessa perspectiva, a posse agrária é uma posse cuja legitimação jurídica pressupõe o cumprimento de tarefas sociais, como garantia de alimentação, de trabalho, de moradia àqueles que a exercem, ou mesmo de proteção ao meio ambiente.

Nessa senda, a proposta desse artigo embrenha-se pelos caminhos da hermenêutica jurídica (GRAU, 2003), em que se tomam os dados normativos como os critérios iniciais para se fazer o juízo sobre se a terra objeto de litígio cumpre ou não a função social. Esses critérios estão positivados na Constituição Federal (art. 186 e incisos), no Estatudo do Terra (art. $2^{\circ}, \S 1$, a, b, c e d) e IV) e no Código Civil (art. 1228, $\$ 1^{\circ}$ ), enquanto partes de um ordenamento jurídico.

\subsection{A Dimensão Socioambiental da Função Social da Terra}

Para esse artigo, escolhe-se, para discussão nas ações possessórias, dentre os condicionantes da função social da terra, aquele socioambiental (art. 186, II, CF/88), pela notoriedade daquilo que se tem chamado, no campo teórico, de "crise ecológica" (BECK, 2002, p. 33) ou de "problemática socioambiental" (LEFF, 2001, p. 73).

No tocante ao critério de proteção ambiental, o juiz, nas ações possessórias, a partir da interpretação sistemática da ordem jurídica brasileira, deverá atentar-se para aquilo que na jurisprudência do STJ vem sendo chamado de "função ecológica do dominio e da posse".

Isso porque, ao menos normativamente, há de prevalecer "hoje a postura de que o dono só é senhor da terra na medida do respeito às aspirações estabelecidas em favor de toda a coletividade e das gerações futuras, entre as quais ganha crescente realce a proteção do meio ambiente" (STJ, SEGUNDA TURMA, Resp. n. ${ }^{\circ}$ 1.240.122/PR, rel. Herman Benjamim, j. 28.06.2011). Proteção essa que expressa uma necessidade decorrente da 
própria "generalização e globalização da problemática socioambiental" (LEFF, 2001, p. 73).

Jurisprudencialmente um instrumento dogmático para se atribuir eficácia à proteção ambiental é a compreensão dos obrigações ambientais como propter rem, como revelam, entre outros, os seguintes precedentes do Superior Tribunal de Justiça: REsp 343741/PR, Rel. Ministro FRANCIULLI NETTO, SEGUNDA TURMA, DJ 7/10/2002; EDcl no AgRg no REsp 255.170/SP, Rel. Ministro LUIZ FUX, PRIMEIRA TURMA, DJ 22/4/2003; REsp 843.036/PR, Rel. Ministro JOSÉ DELGADO, PRIMEIRA TURMA, DJ 9/11/2006; REsp 745.363/PR, Rel. Ministro LUIZ FUX, PRIMEIRA TURMA, DJ 18.10.2007).

E aí é cabivel a aplicação dos textos normativos que condicionam a eficácia da proteção ao meio ambiente - inclusive nas ações possessórias enquanto critério de averiguação da função social da terra - desde aquela superior (texto constitucional) até o mais inferior que esteja conforme aquele. Aqui, por evidente, não é de se desprezar o novo Código Florestal (Lei n. ${ }^{\circ}$ 12.651, de 25 de maio de 2012) enquanto fonte normativa, naquilo evidentemente que não conflitua com os princípios constitucionais e os direitos fundamentais pertinentes ${ }^{6}$.

Nesse caso, todos aqueles fatos que se apresentam, em tese, como atentadores aos valores e interesses que potencializam a ideia de integridade e indisponibilidade do bem jurídico meio ambiente devem ser considerados nas decisões de ações possessórias, senão como prova ao menos como indício de lesão ao meio ambiente, a exemplo do embargo a desmatamento ilegal (art. 51), do uso de fogo em situação em que é proibido (art. 38 e ss.) e do desrespeito ao regime de proteção das áreas de preservação permanente e de reserva legal (arts. $7^{\circ}$ ao $9^{\mathrm{a}}$, e 17 a 24 ), todos referidos na Lei $12.651 / 12$.

Face à unidade do ordenamento, bem assim à sua hierarquização como elemento de caracterização do sistema de direito, resta superada a afirmação de que se separam os juízos possessórios dos petitórios. A Constituição é tida como fundamento de validade do sistema, por isso, em 
qualquer ato hermenêutico, numa perspectiva de interpretação sistemática, seus dispositivos devem ser aplicados.

O método de interpretação sistemático, segundo Ferraz Jr. (2003) pressupõe a consideração da "subordinação e [d]a conexão das normas do ordenamento num todo que culmina (e principia) pela primeira norma origem do sistema, a Constituição)".

Partindo dessa chave de compreensão, os dispositivos constitucionais (arts. 5 , XXII e XXIII, 170, II e III, e 186, I, II, III e IV), que permitem trabalhar com o princípio da função social da terra, devem ser levados em conta em toda e qualquer ação possessória em que se discuta ocupações coletivas de terras por movimentos sociais, sob pena de incorrer-se em inconstitucionalidade material a decisão que a isso não se atentar.

O uso dessa perspectiva interpretativa torna-se ainda mais imprescindivel porque, mesmo no Projeto de Reforma do Código de Processo Civil (PL n. ${ }^{\circ}$ 8046/10 - arts. 540-553) nada é previsto, ao menos literalmente, quanto à exigência de consideração da função social da terra como pressuposto de cabimento das ações possessórias que envolvam conflitos agrários.

A consequência imediata desse descumprimento do principio da função social da terra nas ações possessórias seria a perda da garantia do uso deles para tutelar a posse, ${ }^{7}$ porque carente de um requisito de cabimento. A medida liminar eventualmente postulada seria de ser indeferida e a sentença julgaria improcedente a ação proposta.

Mas a operacionalização disso demanda, entre outros fatores, a mudança de mentalidade daqueles aos quais incumbe aplicar o direito, inclusive com uma abertura ao desenvolvimento teórico da hermenêutica jurídica, notadamente pela assunção da visão de que ao juiz, que não é neutro politicamente, incumbe "a definição da norma de decisão" no caso concreto a partir dos textos normativos válidos (GRAU, 2003). 


\subsection{A Prova da Função Social da Terra nas Ações Possessórias}

$\mathrm{Na}$ apuração fática da funcionalidade da terra nas ações possessórias, deve-se considerar o texto normativo do art. 126, caput e $\S$ único da $\mathrm{CF} / 88$, que diz da presença do juiz nos conflitos envolvendo questões agrárias. A densificação dessa presença poderia se dar, por exemplo, pela necessária realização de inspeção judicial nas possessórias que discutam conflitos agrários.

Ainda que a realização desse tipo de diligência envolva a disponibilidade do juiz para ir ao local do conflito agrário, poderia ser mais usado nesse tipo de lide, para, por exemplo, verificar sobre o que alegado, inclusive sobre o alegado atendimento à função social pelo imóvel rural em disputa e por ser instrumento valioso de convencimento, por permitir o contato direto do juiz com o objeto do litígio, qual seja, a posse do imóvel rural. Se alegado, por exemplo, na inicial, que a fazenda protege o meio ambiente e, na inspeção, for constatado algum dano ambiental de monta, não seria o caso de deferimento de tutela possessória liminar, ao menos nos casos que se entenda necessária a prova do cumprimento da função social para deferir tal forma protetiva.

Outro ponto importante, no tocante à prova dos fatos narrados nessas ações, é a previsão da possibilidade de se designar audiência de justificação prévia da posse, tal como oportunizada pelo art. 928 do Código de Processo Civil. Nos conflitos agrários que originam processos possessórios, seria de grande valia a designação dessa audiência, tanto por prestigiar o contraditório e ampla defesa, quanto por ensejar não apenas melhor instrução sobre o alegado na petição inicial, mas também a participação democrática - pela comunicação obrigatória (SILVA, 1993, p. 264), senão dos réus nominados na inicial ao menos das lideranças de movimentos sociais de luta pela terra - em atos processuais que lhe dizem respeito diretamente, com possibilidade de acompanhamento por advogado e instrução pública e contraditória, inclusive com possibilidade de apresentar contradita e fazer 
reperguntas às testemunhas arroladas pelo(s) autor(es) (SILVA, 1993, p. 265-266). Sem falar, por evidente, da oportunidade de produção de prova sobre se o imóvel rural cumpre ou não a função social.

\section{Conclusão}

Portanto, a textura normativa constitucional, os precedentes invocados e as concepções teóricas apresentadas permitem concluir que é dever do juiz, na apreciação das ações possessórias em que se discutem conflitos agrários, exigir daquele que postula proteção possessória, o cumprimento da função social da terra, tal como gizada normativamente na Constituição, aplicando-se a técnica da interpretação sistemática.

E o Poder Judiciário enquanto referência de convivência democrática tem papel imprescindivel na resolução dos conflitos agrários, num país que se pretende desenvolvido, cabendo-lhe a tarefa de garante das regras e principios constitucionais, inclusive nas ações possessórias, fazendo efetivo o princípio da função social da terra.

No desempenho dessa tarefa, compete ao magistrado responsável pela condução do processo possessório perquirir, seja para deferir ou indeferir a medida liminar postulada ou para julgar procedente ou improcedente a respectiva demanda possessória, sobre se a terra objeto do conflito agrário cumpre ou não sua função social, nos termos do art. $5^{\circ}$, XXII e XXIII, 170, II e III, e 186, I, II, III e IV da CF/88.

O tratamento hermeneuticamente adequado dos textos normativos constitucionais referidos, na perspetiva sistemática, na resolução dos conflitos agrários expressos em ações possessórios, é condição de produção de efeitos desses mesmos textos na redução desses conflitos e na início da desconstrução da estrutura agrária concentrada brasileira a partir dos parâmetros dirigentes da $\mathrm{CF} / 88$. 


\section{LA FONCTION SOCIALE DE LA TERRE ET LAS ACTIONS POSSESSOIRES}

\section{Résumé}

Cet article traite de la relation entre la fonction sociale de la terre et des actions possessoires du point de vue de l'interprétation juridique dans le domaine du droit agraire. Il est soutenu en faveur de la possibilité hermeneutique de discuter la fonction sociale de la terre en actions possessoires (interdit, l'entretien et la restitution) comme une exigence de protection de la possession, dans l'injonction ou dans un jugement. Pour illustrer la façon d'aborder la question dans les actions possessoires, se travail avec l'importance de la possession pour la réalisation de la fonction sociale de la terre, la portée juridique de ce principe dans la loi agraire, avec les critères environnementaux de ce principe et la preuve de la réalisation de ce principe.

Mots-Clés: Droit agraire. Conflits possessoires. Herméneutique juridique.

\section{Notas explicativas}

1 Segundo Teixeira (2011)," tomando-se os dados de 2010, contabilizamos no Brasil, 69,2 mil grandes propriedades improdutivas, com área equivalente a 228,5 milhões de hectares. De acordo com o Censo Agropecuário de 2006, há 94 milhões de hectares com matas e ou florestas naturais (incluindo-se 50,2 milhões de terras destinadas às Áreas de Proteção Permanentes e Reservas Legais). Subtraindo-se toda a área com matas e florestas naturais (não apenas das grandes) da área total das grandes porções improdutivas, conclui-se que haveria no Brasil uma área improdutiva, dentro das grandes propriedades improdutivas, pelo menos 134 milhões de hectares. (Disponivel em:

$<$ http:/ /amaivos.uol.com.br/amaivos09/noticia/noticia.asp?cod_noticia=18 568\&cod_canal=41.>. Acesso em: 10 out. 2013).

2 Trata-se do relatório final, publicado em 2012, sobre o OBSERVATÓRIO DA ATUAÇÃO DO PODER JUDICIÁRIO NOS CONFLITOS AGRÁRIOS DECORRENTES DE OCUPAÇÕES DE TERRA POR MOVIMENTOS SOCIAIS NOS ESTADOS DO PARÁ, MATO GROSSO, GOIÁS E PARANÁ (2003-2011), desenvolvido no Programa de Mestrado em Direito Agrário da UFG, com financiamento do Observatório da Justiça Brasileira, que mantem parceria com a Secretaria de Reforma do Judiciário do Ministério da Justiça (SRJ/MJ) e com a Fundação Ford.

3 Para uma verificação de precedentes jurisprudenciais sobre a discussão da função social da propriedade e/ou da posse em ações possessórias, ver TORRES (2010). 
4 Aqui os questionamentos são postos apenas como reforço da importância do tema discutido. As tentativas de resposta são para outros trabalhos ou para os mais capazes. No campo doutrinário, há muito material sobre isso. Ver, entre outros, BECKER, Laércio. A repercussão da função social da propriedade no Processo Civil. In: Genesis - Revista de Direito Processual Civil, vol. 4, Curitiba, 1997.

5 Vale-se aqui do conceito de concretização como "o processo de reconstrução do Direito aplicável ao caso, à luz do padrão constitucional e através de um procedimento argumentativo e racionalmente controlável" (PEREIRA, 2001, p. 164). O parâmetro de concretização da função social da terra, a ser feita pelo juiz em cada caso concreto, no procedimento especial das ações possessórias, é o texto normativo do art. 186, conjugado com o art. $5^{\circ}$, incisos XXII e XXIII, todos da $\mathrm{CF} / 88$, numa leitura hermenêutica sistemática. O que exige necessariamente todo um afazer hermenêutico na âmbito jurisdicional, em que texto normativo, caso concreto e atuação do intérprete se mostram imprescindiveis.

6 Para os fins destes artigos, reputa-se que muito do que lá está positivado não suportaria um controle de constitucionalidade, seja na via concentrada ou difusa, já que insere no circuito mercadológico os bens ambientais indisponiveis, a exemplo dos serviços ambientais, positivando o objetivo de criação de um mercado de serviços ambientais (art. $41, \S 5^{\circ}$ ), do programa de regularização ambiental das propriedades rurais, no que toca a prescrição de "esquecimento" dos danos consolidados anteriormente a 22 de julho de 2008; da possibilidade de emissão da Cota de Reserva Ambiental como título nominativo (art. 44) etc.

7 Fundamentam essa conclusão a lição de Comparato (2000), que afirma que "quem não cumpre a função social da propriedade perde as garantias, judiciais e extrajudiciais, de proteção da posse, inerentes à propriedade, como o desforço privado imediato e as ações possessórias" e a lição de Marés (2003, p. 117), segundo a qual “[...] o proprietário que não obra no sentido de fazer cumprir a função social de sua terra, perde-a, ou não tem direito a ela. Ou, dito de forma mais concorde com a Constituição, não tem direito à proteção, enquanto não faz cumprir sua social função".

\section{Referências}

ALFONSIN, Jacques Távora. Os conflitos possessórios e o Judiciário: três reducionismos processuais de solução. In: SILVEIRA, Domingos Sávio Dresch da; XAVIER, Flávio Sant'anna (Orgs.). O direito agrário em debate. Porto Alegre: Livraria do Advogado, 1998. 
ANDRADE, Vera Regina Pereira. Sistema pena máximo x cidadania minima: códigos da violência na era da globalização. Porto Alegre: Livraria do Advogado, 2003.

ARONNE, Ricardo. Titularidades e apropriação no Código Civil brasileiro breve ensaio sobre a posse e sua natureza. In: SARLET, Ingo Wolfgang (Org.). O novo Código Civil e a Constituição. Porto Alegre: Livraria do Advogado, 2003.

BECK, Ulrich. La sociedade del riesgo global. Trad. Jesús Alborés Rey. Madrid: Siglo Veintiuno, 2002.

BECKER, Laércio. A repercussão da função social da propriedade no Processo Civil. In: Genesis - Revista de Direito Processual Civil, vol. 4, Curitiba, 1997.

BERSONE, Darcy. Da posse. São Paulo: Saraiva, 1996.

BRASIL. SUPERIOR TRIBUNAL DE JUSTIÇA. REsp 343741/PR, Rel. Ministro FRANCIULLI NETTO, SEGUNDA TURMA, DJ 7/10/2002.

. SUPERIOR TRIBUNAL DE JUSTIÇA. EDcl no AgRg no REsp 255.170/SP, Rel. Ministro LUIZ FUX, PRIMEIRA TURMA, DJ 22/4/2003.

. SUPERIOR TRIBUNAL DE JUSTIÇA. REsp 843.036/PR, Rel. Ministro JOSÉ DELGADO, PRIMEIRA TURMA, DJ 9/11/2006.

SUPERIOR TRIBUNAL DE JUSTIÇA. REsp 745.363/PR, Rel. Ministro LUIZ FUX, PRIMEIRA TURMA, DJ 18.10.2007.

BRASIL. TRIBUNAL DE JUSTIÇA DO RIO GRANDE DO SUL. AGRAVO DE INSTRUMENTO N. 598.360.402 - SÃO LUIZ GONZAGA - Relatora Desembargadora Elba Aparecida Nicolli Bastos, j. 06.1021998 Disponivel: http:/ / www.pge.sp.gov.br/centrodeestudos/bibliotecavirtual/dh/volume\%20ii/agr avo598360402.htm. Acesso em: 09 jan. 2011.

TRIBUNAL DE JUSTIÇA DO RIO GRANDE DO SUL. Agravo de Instrumento $\mathrm{N}^{\circ}$ 70003434388, Décima Nona Câmara Cível, Tribunal de Justiça do RS, Relator: Carlos Rafael dos Santos Júnior, Julgado em 06/11/2001. Disponivel em: < http://www.tjrs.jus.br/site/>. Acesso em: 19 jun. 2012.

CÂMARA DOS DEPUTADOS. PROJETO DE LEI N. 8046/2010. Disponivel em: <http://www.camara.gov.br/proposicoesWeb/prop_mostrarintegra?codteor $=92185$ 9\&filename=Avulso+-PL+8046/2010. >. Acesso em: 10 out. 2013. 
BUSSADA, Wilson. Reintegração de posse: interpretação pelos tribunais. São Paulo: Javoli, 1988.

CAMARGO, Maria Lacombe Camargo. Hermenêutica e argumentação: uma contribuição ao estudo do direito. 3. ed. Rio de Janeiro: Renovar, 2003.

COMPARATO. Fábio Konder. Direitos e deveres fundamentais em matéria de propriedade. In: STROZAKE, Juvelino José (Org.). A questão agrária e a justiça. São Paulo: Revista dos Tribunais, 2000.

FRANCO, Rangel Donizete; LEITE FILHO; Antonio Henriques Lemos. Institutos constitucionais agrários: regras ou principios? In: Revista Novos Direitos, UNIFAN, Aparecida de Goiânia-GO, n. 1, v. 1, p. 209-226, 2011.

FERRAZ JÚNIOR, Tércio Sampaio. Introdução ao estudo do direito: técnica, decisão e dominação. São Paulo: Atlas, 2003.

GRAU, Eros Roberto. Ensaio e discurso sobre a interpretação/aplicação do direito. 2. ed. São Paulo: Malheiros, 2003.

GOMES, Orlando. Direitos reais. Rio de Janeiro: 1998.

IHERING, Rudolf von. Teoria Simplificada da Posse. São Paulo: Edipro, 2002 .

LEFF, Enrique. Epistemologia ambiental. Trad. Sandra Valenzuela. São Paulo: Cortez, 2001.

LIMA, Getúlio Targino. A posse agrária sobre bem imóvel: implicações no direito brasileiro. Dissertação (Mestrado) - Curso de Pós-Graduação em Direito Agrário, UFG, Goiânia, 1990.

MARÉS, Carlos Frederico. Função social da terra. Porto Alegre: Fabris, 2003.

MARQUES, Benedito Ferreira. Direito agrário brasileiro. 6. ed. Goiânia: AB editora, 2005.

NASCIMENTO, Tupinambá Miguel Castro do. Posse e propriedade (doutrina). Rio: Aide, 1986.

PACHECO, José Ernani de Carvalho. Interditos possessórios. 8. ed. Curitiba: Juruá, 1996.

PEREIRA, Rodolfo Viana. Hermenêutica filosófica e constitucional. Belo Horizonte: Del Rey, 2001. 
ROSA, Alexandre Morais da. Decisão penal: a bricolage de significantes. Rio de Janeiro: Lumen Juris, 2006.

SAVIGNY, Frédéric Charles de. Traité de la possession en droit romain. Trad. Henre Staedtler. 2. ed. Paris: Libraires Editeurs, 1870. Disponivel em: http://archive.org/stream/traitdelaposses01staegoog\#page/n8/mode/2up.. Acesso em: 19 jun. 2012.

SILVA, Ovídio A. Baptista da. Procedimentos especiais: exegese do Código de Processo Civil (art. 890 a 981). Rio de Janeiro: Aide, 1993.

TÁRREGA, Maria Cristina Vidotte Blanco. Et al. Observatório da atuação do Poder Judiciário nos conflitos agrários decorrentes de ocupaçoes de terra por movimentos sociais nos estados do Pará, Mato Grosso, Goiás e Paraná (2003-2011): Relatório Final de Pesquisa/ Maria Cristina Vidotte Blanco Tárrega, Cláudio Lopes Maia, Adegmar José Ferreira - Goiânia: UFG/FD, 2012.

TEIXEIRA, Gerson. Agravamento da concentração de terras. Disponível em: $\quad<$ http://www.mst.org.br/Gerson-Teixeira-agravamento-daconcentracao-das-terras>. Acesso em: 10 out. 2013.

TORRES, Marcos Alcino de Azevedo. A propriedade e a posse: um confronto em torno da função social. 2. ed. Rio de Janeiro: Lumen Juris, 2010.

ZIEGLER, Jean. Senhores do crime: as novas máfias contra a democracia. Trad. Clóvis Marques. Rio de Janeiro/São Paulo: Record, 2003.

Artigo submetido para avaliação em 21 de outubro de 2013 e aceito para publicação em 17 de dezembro de 2013. 